\title{
Gambaran Perilaku Pencarian Pengobatan Pada Mahasiswa Fakultas Kesehatan Masyarakat Universitas Airlangga
}

\author{
Description of Health Seeking Behavior among Public Health \\ Students, Airlangga University
}

\author{
Wahyu Mila Febriani \\ Departemen Administrasi dan Kebijakan Kesehatan \\ Fakultas Kesehatan Masyarakat, Universitas Airlangga, Surabaya \\ Email : milafebriani28@gmail.com
}

\begin{abstract}
Background: Health seeking behavior is an individual effort to find right treatment to overcome health problem. Students as individuals who are considered capable of selfresponsibility have power over themselves to determine their behavior. Objective: This study aims to determine the description of health seeking behavior in students of Public Health Faculty of Airlangga University. Method: This study is an observational analytic that used cross sectional design and was analyzed using chi-square statistical analysis. The population were 2462 students of Faculty of Public Health, Airlangga University and 96 students were selected randomly as a sample by simple random sampling technique. The variables in this research are health seeking behavior as dependent variable, whereas perceived seriousness, perceived susceptibility, perceived benefits and perceived barriers as independent variables. Result: The results of this study showed that the number of students of Public Health Faculty of Airlangga University who took treatment action when they felt the symptoms of disease were 37.5\%. Statistical tests showed that perceived seriousness $(P$ value $=0.176)$ and perceived benefit $(P$ value $=0.446)$. While perceived susceptibility $(P$ value $=0,003)$ and perceived barriers $(P$ value $=0,005)$. Conclusion: Perceived susceptibility and perceived barriers have a significant impact to health seeking behavior among the students of Public Health Faculty of Airlangga University.
\end{abstract}

Keywords : students, health seeking, behavior, health belief model

\begin{abstract}
ABSTRAK
Latar belakang: Perilaku pencarian pengobatan merupakan segala tindakan atau upaya yang dilakukan oleh individu dengan tujuan menemukan pengobatan yang tepat saat merasa/menganggap dirinya sedang memiliki gangguan kesehatan. Mahasiswa sebagai individu yang sudah dianggap mampu bertanggung jawab atas diri sendiri memiliki kuasa atas dirinya untuk menentukan perilakunya, termasuk dalam upaya pencarian pengobatan. Tujuan: Penelitian ini bertujuan untuk mengetahui gambaran perilaku pencarian pengobatan pada mahasiswa Fakultas Kesehatan Masyarakat Universitas Airlangga. Method: Jenis penelitian yang digunakan adalah observasional analitik dengan studi korelasi chi-square dan rancang bangun cross sectional. Sampel penelitian berjumlah 96 mahasiswa yang diambil dari total populasi sebesar 2462 mahasiswa FKM UNAIR dan dipilih secara acak menggunakan teknik sampel acak sederhana. Variabel pada penelitian ini terdiri dari perilaku pencarian pengobatan sebagai variabel terikat, sedangkan persepsi kerentanan, persepsi keseriusan, persepsi manfaat dan persepsi hambatan sebagai variabel bebas. Hasil: Hasil penelitian menunjukkan bahwa jumlah mahasiswa Fakultas Kesehatan Masyarakat Universitas Airlangga yang melakukan tindakan pengobatan saat pertama kali merasakan gejala penyakit sebesar 37,5\%. Berdasarkan hasil uji statistik dapat diketahui jika variabel perceived seriousness $(P$ value $=0,176)$ dan perceived benefit ( $P$ value $=0,446)$. Sedangkan variabel perceived susceptibility $(P$ value $=$ $0,003)$ dan perceived barriers $(P$ value $=0,005)$. Kesimpulan: Terdapat hubungan antara persepsi kerentanan dan hambatan yang dirasakan dengan timbulnya perilaku pencarian
\end{abstract}


194 Jurnal Promkes: The Indonesian Journal of Health promotion and Health Education Vol. 7 No. 2 Desember 2019 : 193 - 203, doi: 10.20473/jpk.V7.12.2019.193-203

pengobatan pada mahasiswa Fakultas Kesehatan Masyarakat Universitas Airlangga, Surabaya.

Kata Kunci : Mahasiswa, perilaku, pencarian pengobatan, health belief model

\section{PENDAHULUAN}

Sakit merupakan suatu hal yang tidak dapat diprediksi kedatangannya. Sepanjang hidupnya, manusia pasti pernah mengalami atau menderita suatu penyakit. Saat seseorang mengalami suatu penyakit, secara naluriah ia akan melakukan usaha untuk menyembuhkan penyakitnya dengan segala cara. Berbagai upaya yang seringkali dilakukan saat menderita suatu penyakit, antara lain mengobati sendiri (membeli obat warung atau apotek), berobat ke pelayanan kesehatan ataupun ke pelayanan kesehatan tradisional.

Perilaku pencarian pengobatan merupakan segala tindakan atau upaya yang dilakukan oleh individu dengan tujuan menemukan obat yang tepat saat merasa atau menganggap dirinya sedang memiliki masalah kesehatan. Perilaku pencarian pengobatan didahului oleh proses pengambilan keputusan yang selanjutnya diatur oleh individu, perilaku rumah tangga, norma masyarakat, serta harapan terhadap penyedia layanan kesehatan. Masyarakat yang menderita suatu penyakit namun tidak merasa bahwa penyakit tersebut mengancam jiwanya, tentu tidak akan bertindak untuk melakukan pengobatan. Namun, jika mereka merasa penyakit yang diderita mengganggu aktifitas ataupun dapat mengancam jiwa barulah timbul suatu perilaku dan usaha (Trisnawan, 2015).

Di Amerika Serikat upaya pencarian pengobatan dengan cara pengobatan sendiri memiliki prevalensi yang cukup tinggi yakni mencapai 75\% (Al-ameri, Albadri and Lafta, 2016). Di Malaysia sebanyak 66,7\% memilih untuk berobat ke tenaga kesehatan saat mengalami gangguan kesehatan dan hanya 20,9\% yang melakukan pengobatan sendiri (Dawood, 2017).

Di Indonesia, sebanyak 55,8\% rumah tangga memilih untuk mengobati sendiri jika menderita suatu penyakit. Sedangkan $44,2 \%$ yang lainnya mencari pengobatan ke fasilitas kesehatan jika menderita gangguan kesehatan (Kementerian Kesehatan RI, 2010), sedangkan hasil Riskesdas tahun 2013 besaran rumah tangga yang menyimpan obat untuk upaya pengobatan yang dilakukan sendiri (swamedikasi) sebanyak 35,2\%. Rata-rata obat yang disimpan adalah obat yang sedang digunakan sebesar $32,1 \%$, obat persediaan sebesar $42,2 \%$ dan sebanyak $47,0 \%$ rumah tangga menyimpan obat sisa. Kondisi tersebut menunjukkan bahwa masyarakat Indonesia lebih memilih mengobati diri sendiri saat merasakan gejala sakit. Padahal perilaku mengobati diri sendiri dengan membeli obat bebas, baik di apotek ataupun obat warung memiliki risiko ketidaktepatan dosis atau jenis obat. Sejak tahun 2009 hingga tahun 2014 persentase masyarakat di Indonesia yang memilih untuk mengobati sendiri melalui upaya swamedikasi daripada berobat ke pelayanaan kesehatan saat memiliki keluhan kesehatan masih cukup besar.

Hasil survei sosial ekonomi nasional (Susenas) tahun 2009 hingga 2014 persentase penduduk yang memilih mengobati sendiri mengalami penurunan (Badan Pusat Statistik, 2009). Tahun 2009 sebesar $68,41 \%$ penduduk memilih untuk melakukan swamedikasi saat megalami keluhan kesehatan dan pada tahun 2014 turun pada angka $61,05 \%$. Kondisi tersebut dapat menjadi indikasi bahwa masyarakat mulai percaya dan terbuka untuk melakukan pengobatan di pelayanan kesehatan, namun persentase tersebut masih menunjukkan lebih dari 50\% masyarakat di Indonesia memilih untuk melakukan pengobatan sendiri (swamedikasi) dibandingkan melakukan pengobatan di pelayanan kesehatan.

Secara umum saat mengalami gangguan kesehatan, masyarakat akan berusaha mengobati diri sendiri terlebih dahulu, baik dengan ramuan tradisional maupun dengan obat yang bisa dibeli secara bebas. Jika tidak ada perubahan atau belum ada hasil, barulah mencari pengobatan di pelayanan kesehatan. Hal tersebut juga yang seringkali dilakukan

C2019. Jurnal Promkes: The Indonesian Journal of Health Promotion and Health 
oleh mahasiswa saat mengalami gangguan kesehatan. Mahasiswa seringkali dianggap memiliki pengetahuan yang lebih baik dibandingkan masyarakat lain yang tidak menempuh pendidikan tinggi, sehingga seringkali perilaku mahasiswa dijadikan contoh atau panutan dalam kehidupan sehari-hari termasuk di dalamnya perilaku pencarian pengobatan.

Penelitian yang dilakukan oleh Raflis (2013) pada mahasiswa fakultas non-eksakta Universitas Sumatera Utara diperoleh hasil sebanyak lebih dari 70\% responden segera melakukan pengobatan jika merasa sakit (Keloko, Harahap and Raflis, 2013). Sebanyak 61,1\% mahasiswa mengkonsumsi obat warung dan $81,1 \%$ memilih untuk berobat ke fasilitas kesehatan.

Data statistik pemuda tahun 2016 menunjukkan lebih dari $45 \%$ pemuda telah melakukan upaya berobat jalan dalam mengatasi keluhan kesehatan yang diderita. Angka tersebut mengalami penurunan pada tahun 2017, dimana angka berobat jalan yang dilakukan oleh pemuda di Indonesia yang berada pada kelompok usia 18-30 tahun hanya mencapai 36,35\%. Masih terdapat lebih dari separuh pemuda yang tidak melakukan upaya berobat jalan dengan alasan terbanyak adalah pemuda dapat mengobati diri sendiri sebanyak 68,42\% dan hampir $30 \%$ merasa tidak perlu melakukan upaya pengobatan. Angka swamedikasi yang tinggi (upaya pengobatan sendiri) dapat dipengaruhi oleh beberapa faktor seperti tingkat pendidikan, keluarga, masyarakat, ketersediaan obat serta paparan iklan dari media (Bennadi, 2013). Pengobatan modern menjadi tempat pengobatan yang lebih banyak dipilih oleh pemuda dibandingkan pengobatan tradisional.

Health Belief Model adalah teori yang dirancang untuk mendorong masyarakat melakukan perilaku kesehatan ke arah yang baik. Teori Health Belief Model didasarkan pada kepercayaan bahwa perilaku kesehatan ditentukan oleh persepsi kerentanan terhadap masalah kesehatan (perceived susceptibility), persepsi keseriusan atau keparahan terhadap masalah kesehatan (perceived seriousness), persepsi manfaat yang didapatkan dari pengobatan atau upaya pencegahan (perceived benefit), serta persepsi hambatan yang dirasakan (perceived barriers).
Trisnawan (2015) menyebutkan faktor yang mempengaruhi perilaku pencarian pengobatan adalah persepsi individu itu sendiri yang terdiri dari perceived susceptibility, perceived seriousness, perceived benefit, dan perceived barriers. Penelitian ini bertujuan untuk mengetahui gambaran perilaku pencarian pengobatan pada mahasiswa Fakultas Kesehatan Masyarakat Universitas Airlangga dengan kajian menggunakan model teori Health Belief Model (Trisnawan, 2015).

\section{METODE}

Bentuk penelitian yang digunakan adalah deskriptif analitik, dimana penelitian ini menggambarkan perilaku pencarian pengobatan pada mahasiswa Fakultas Kesehatan Masyarakat Pendekatan yang digunakan adalah kuantitatif dan model non eksperimental dengan studi korelasi. Rancang bangun penelitian ini adalah cross sectional, karena variabel penelitian diambil pada waktu bersamaan.

Populasi penelitian adalah seluruh mahasiswa Fakultas Kesehatan Masyarakat Universitas Airlangga dengan jumlah 2462 mahasiswa, dimana jumlah tersebut diperoleh dari website resmi Universitas Airlangga tahun 2018. Teknik yang digunakan dalam pengambilan sampel penelitian adalah tekniksimple random sampling.

Noor (2015) menyatakan, simple random sampling adalah teknik pengambilan sampel yang dipilih secara random, dimana setiap unsur dalam populasi mempunyai kesempatan yang sama untuk bisa dipilih menjadi sampel (Noor, 2015). Penentuan besar sampel menggunakan rumus slovin dengan rumus sebagai berikut:

$$
n=\frac{N}{1+N\left(d^{2}\right)}
$$

Keterangan :

$\mathrm{N}$ : Jumlah Populasi

$\mathrm{n}$ : Besar Sampel

d : Tingkat Kesalahan $(0,1)$

Sehingga dilakukan perhitungan sebagai berikut :

$$
\begin{aligned}
n & =\frac{2462}{1+2462\left(0,1^{2}\right)} \\
& =96,1
\end{aligned}
$$

Hasil perhitungan tersebut menunjukkan besar sampel yang digunakan dalam penelitian sebanyak 96 orang mahasiswa 
Fakultas Kesehatan Masyarakat Universitas Airlangga.

Sumber data yang digunakan berasal dari sumber data primer yang dihimpun melalui penyebaran kuesioner. Variabel yang dianalisis dalam penelitian ini mengacu pada teori Health Belief Model, yang mana teori tersebut memiliki empat persepi yang dapat menjadi prediktor dalam perilaku kesehatan, yakni perceived susceptibility, perceived seriousness, perceived benefit, dan perceived barriers (Rosenstock, Strecher and Becker, 1988). Keempat persepsi tersebut menjadi variabel independent (bebas) dalam penelitian ini. Variabel dependent atau variabel terikat adalah perilaku pencarian pengobatan.

Persepsi keseriusan diukur dengan memunculkan pendapat pada instrumen berupa anggapan bahwa penyakit yang diderita akan semakin parah, penyakit yang diderita dapat mengancam hidup, penyakit yang diderita dapat mengganggu aktivitas sehari-hari dan anggapan adanya rasa cemas jika penyakit tidak kunjung sembuh. Selanjutnya, persepsi keseriusan dikategorikan menjadi 2 kategori yaitu, tidak serius dan serius.

Persepsi yang kedua adalah perceived susceptibility (kerentanan) yang dirasakan. Pengukuran kerentanan dilakukan dengan memunculkan pernyataan pada instrumen penelitian terkait persepsi. Pernyataan tersebut menyebutkan bahwa kurangnya aktivitas fisik menjadi pemicu masalah kesehatan, gaya hidup yang kurang baik dapat meningkatkan resiko kesehatan, gangguan kesehatan serius dapat menyerang setiap orang termasuk remaja, serta pengaruh lingkungan dapat meningkatkan resiko gangguan kesehatan. Persepsi kerentanan dalam penelitian ini dikategorikan menjadi tidak rentan dan rentan.

Persepsi ketiga yang digunakan sebagai variabel penelitian adalah perceived benefit. Pengukuran persepsi adanya manfaat yang dirasakan atas perilaku yang akan dilakukan, dimunculkan dengan pernyataan tentang anggapan bahwa istirahat dan atau minum obat yang dijual bebas (warung ataupun apotik) dapat menyembuhkan penyakit yang diderita, anggapan bahwa pergi ke fasilitas kesehatan dapat mempercepat kesembuhan, serta rasa aman jika diobati oleh tenaga kesehatan. Persepsi manfaat dalam penelitian ini dikategorikan menjadi tidak bermanfaat dan bermanfaat.

Persepsi terakhir yang menjadi variabel terikat dalam penelitian adalah perceived barriers. Persepsi hambatan yang muncul jika melakukan suatu perilaku diukur dengan adanya pernyataan tentang persepsi dampak negatif yang ditimbulkan jika terlalu sering minum obat, melakukan pengobatan jika disuruh, rasa malas untuk pergi ke pelayanan kesehatan serta anggapan menghabiskan waktu dan biaya. Persepsi hambatan ini dikategorikan menjadi 2 kategori yaitu, tidak ada hambatan dan ada hambatan.

\section{HASIL DAN PEMBAHASAN}

Gambaran karakteristik responden yang dilibatkan dalam penelitian disajikan pada Tabel 1:

Tabel 1. Distribusi Frekuensi Karakteristik Responden di FKM UNAIR tahun 2018

\begin{tabular}{|c|c|c|}
\hline Karakteristik & Frekuensi & $\%$ \\
\hline \multicolumn{3}{|l|}{ Jenis Kelamin } \\
\hline Laki-laki & 26 & 27,08 \\
\hline Perempuan & 70 & 72,92 \\
\hline Total & 96 & 100 \\
\hline \multicolumn{3}{|l|}{ Umur } \\
\hline $18-19$ th & 13 & 13,5 \\
\hline$>19-21$ th & 46 & 47,9 \\
\hline$>21$ th & 37 & 38,5 \\
\hline Total & 96 & 100 \\
\hline \multicolumn{3}{|c|}{ Kepemilikan Asuransi } \\
\hline $\mathrm{Ya}$ & 86 & 89,6 \\
\hline Tidak & 10 & 10,4 \\
\hline Total & 96 & 100 \\
\hline \multicolumn{3}{|l|}{ Jenis Asuransi } \\
\hline BPJS/KIS & 81 & 84,4 \\
\hline Asuransi Komersial & 5 & 5,2 \\
\hline Tidak Punya & 10 & 10,4 \\
\hline Total & 96 & 100 \\
\hline \multicolumn{3}{|l|}{ Metode Pembayaran } \\
\hline BPJS/KIS & 45 & 46,9 \\
\hline Asuransi Komersial & 4 & 4,2 \\
\hline $\begin{array}{l}\text { Umum (out of } \\
\text { pocket) }\end{array}$ & 47 & 49,0 \\
\hline Total & 96 & 100 \\
\hline
\end{tabular}

Tabel 1 dapat diketahui jika mayoritas responden berjenis kelamin perempuan $(72,29 \%)$ dan mayoritas responden berada pada rentang usia $>19$ $21(47,9 \%)$. Hasil tersebut sejalan dengan studi yang dilakukan oleh Adhyka (2013) tentang gambaran perilaku mahasiswa Fakultas Kesehatan terkait proses pencarian pengobatan, dimana pada penelitian tersebut mayoritas responden 
berjenis kelamin perempuan dan berada pada kelompok usia 19-20 tahun (Adhyka, Bakti and Lumongga, 2013). Kondisi tersebut mengindikasikan bahwa terdapat kesamaan karakteristik responden, dimana karakteristik individu (usia dan jenis kelamin) dapat mempengaruhi keputusan seseorang dalam melakukan pembelian, termasuk pembelian jasa/pelayanan kesehatan (Supriyanto and Ernawati, 2010).

Tabel 1 juga menunjukkan bahwa mayoritas mahasiswa FKM UNAIR yang menjadi responden penelitian telah memiliki asuransi kesehatan sebesar 89,6\%. Mayoritas responden memiliki asuransi berupa BPJS Kesehatan $(84,4 \%)$, namun angka pemanfaatan BPJS di kalangan mahasiswa Fakultas Kesehatan Masyarakat Universitas Airlangga masih di bawah $50 \%$, yakni hanya mencapai $46,9 \%$. Sebagian dari mereka lebih memilih menjadi pasien umum atau membayar sendiri biaya pelayanan kesehatan dengan proporsi sebanyak $49 \%$.

Kondisi tersebut sejalan dengan Survei Sosial Ekonomi Nasional (Susenas) pada tahun 2017 menunjukkan persentase pemuda Indonesia yang menggunakan jaminan kesehatan untuk pengobatan rawat jalan khususnya, hanya mencapai $37,43 \%$, yang mana angka tersebut mengalami kenaikan yang cukup signifikan bila diba (Badan Pusat Statistik, 2017). Karena pada susenas tahun 2015 angka pemanfaatan jaminan kesehatan oleh pemuda hanya sebesar 5,59\% (Badan Pusat Statistik, 2015).

Penelitian yang dilakukan oleh Rumengan (2015) menyebutkan, unsur yang dapat mempengaruhi penggunaan pelayanan kesehatan oleh peserta BPJS adalah pemahaman individu terhadap JKN, kemudahan akses, serta persepsi atas sikap atau tindakan petugas kesehatan di fasilitas kesehatan. Responden yang memiliki persepsi baik terhadap BPJS/JKN memiliki kesempatan 3,1 kali lebih besar menggunakan pelayanan kesehatan (Rumengan, Umboh and Kandou, 2015).

Sebagai mahasiswa fakultas kesehatan, seharusnya responden memiliki persepsi yang cukup baik terhadap BPJS, karena mereka mendapatkan informasi lebih banyak dan lebih sering dibandingkan dengan masyarakat ataupun mahasiswa nonkesehatan. Iswandi (2017) menyebutkan, kepemilikan BPJS menjadi salah satu faktor yang mempengaruhi masyarakat untuk datang ke pelayanan kesehatan sebagai upaya pencarian pengobatan, karena kemudahan dan manfaat yang diberikan atau didapatkan sebagai peserta asuransi sosial milik pemerintah (Iswandi, 2017).

Penelitian ini melihat tindakan awal yang dilakukan oleh mahasiswa sebagai responden saat merasakan gangguan kesehatan.

Tabel 2. Gambaran health seeking behavior pada mahasiswa FKM UNAIR tahun 2018

\begin{tabular}{|c|c|c|}
\hline Kategori & Frekuensi & $\%$ \\
\hline $\begin{array}{l}\text { Tidak mencari } \\
\text { pengobatan }\end{array}$ & 60 & $62,5 \%$ \\
\hline Mencari Pengobatan & 36 & $37,5 \%$ \\
\hline Total & 96 & $100 \%$ \\
\hline
\end{tabular}

Tabel 2 kmenujukkan bahwa mayoritas mahasiswa FKM UNAIR yang menjadi responden tidak melakukan upaya pencarian pengobatan ketika menghadapi masalah kesehatan dengan persentase sebesar $62,5 \%$. Proses pertama dalam tindakan pencarian pengobatan ialah mengidentifikasi gejala penyakit yang diderita. Mahasiswa kesehatan dianggap mempunyai pemahaman yang baik tentang kesehatan serta apa yang harus dilakukan saat merasakan gangguan kesehatan, karena mereka lebih sering mendapatkan paparan informasi terkait hal tersebut.

Hasil penelitian ini menunjukkan bahwa mahasiswa kesehatan yang dianggap memiliki pengetahuan tentang kesehatan, tidak melakukan pencarian pengobatan saat menderita gejala penyakit. Kebanyakan dari mereka lebih memilih membiarkan kondisi tersebut, jika mereka beranggapan bahwa gangguan kesehatan yang dialami belum terlalu parah, padahal pihak Universitas Airlangga telah menyediakan pusat layanan kesehatan (PLK) disetiap kampus. Keberadaan PLK ini dapat menjadi faktor pendorong bagi mahasiswa untuk melakukan tindakan pengobatan.

Penelitian yang dilakukan oleh Vaz (2012) di Universitas Goa India terkait perilaku pengobatan mahasiswa didapatkan hasil bahwa sebanyak 31,3\% mahasiswa melakukan diagnosa sendiri gejala sakit yang dirasakan (Vaz, Ferreira and Kulkarni, 2012). Sebagian besar 
mahasiswa (66,3\%) juga memilih untuk melakukan pengobatan sendiri daripada berobat ke pelayanan kesehatan atau tenaga kesehatan. Kondisi ini menunjukkan bahwa mahasiswa Universitas Goa India belum menganggap upaya pengobatan adalah hal penting yang harus dilakukan.

Teori Health Belief Model menjelaskan bahwa keinginan seseorang untuk berperilaku positif dalam hal kesehatan dipengaruhi oleh dua faktor utama, yakni tingkat dimana suatu gangguan kesehatan dianggap sebagai suatu ancaman oleh individu serta sejauh mana perilaku kesehatan yang dilakukan diyakini secara efektif dapat mengurangi risiko kesehatan. Gangguan kesehatan di masyarakat seringkali dipersepsikan berbeda tiap masing-masing individu.

Perceived seriousness dapat didefinisikan sebagai keseriusan yang dirasakan oleh individu terhadap gangguan kesehatan yang dialami. Tabel 3 menunjukkan gambaran persepsi keseriusan yang dirasakan oleh responden.

Tabel 3. Gambaran Perceived Seriousness yang Dirasakan terhadap Health Seeking Behavior pada Mahasiswa FKM UNAIR Tahun 2018

\begin{tabular}{|c|c|c|c|c|c|c|c|}
\hline \multirow{3}{*}{$\begin{array}{l}\text { Perceived } \\
\text { Seriousness }\end{array}$} & \multicolumn{4}{|c|}{ Pencarian Pengobatan } & \multirow{2}{*}{\multicolumn{2}{|c|}{ Total }} & \multirow{3}{*}{ P Value } \\
\hline & \multicolumn{2}{|c|}{ Tidak } & \multicolumn{2}{|l|}{$\mathrm{Ya}$} & & & \\
\hline & Frekuensi & $\%$ & Frekuensi & $\%$ & Frekuensi & $\%$ & \\
\hline Tidak serius & 40 & 67,8 & 19 & 32,2 & 59 & 100 & O 256 \\
\hline Serius & 20 & 54,1 & 17 & 45,9 & 37 & 100 & U,Zכ6 \\
\hline
\end{tabular}

Tabel 4 menunjukkan gambaran Perceived Seriousness responden terhadap upaya untuk mencari pengobatan. Hasil penelitian menunjukkan bahwa sebagian besar responden yang memiliki persepsi serius terhadap penyakit justru tidak berupaya untuk mencari pengobatan.

Nilai $\mathrm{p}$ yang diperoleh dari hasil uji chi square menunjukkan angkasebesar 0,256 pada derajat kemaknaan sebesar 5\%. Nilai tersebut menunjukkan bahwa tidak ada hubungan yang signifikan antara persespi keseriusan (perceived seriousness) dengan perilaku pencarian pengobatan pada mahasiswa Fakultas Kesehatan Masyarakat UNAIR. Hasil ini memperlihatkan bahwa mahasiswa yang memiliki persepsi serius terhadap masalah kesehatan yang dialami tidak berpengaruh terhadap upaya perilaku pencarian pengobatan mereka.

Hasil yang serupa juga diperoleh dari penelitian Trisnawan (2015) dimana tidak ada hubungan yang signifikan antara perceived seriousness dengan health seeking behavior mahasiswa serumpun fakultas kesehatan di Universitas Sumatera (Trisnawan, 2015). Padahal menurut teori health belief model jika seseorang memiliki persepsi serius tentang keadaan dirinya, maka hal tersebut akan menggerakkan seseorang untuk melakukan perilaku kesehatan.

Gangguan kesehatan atau penyakit seringkali dipersepsikan berbeda oleh masing-masing individu. Persepsi individu menurut Robbins \& Judge (2012) dapat dipengaruhi oleh faktor internal dan faktor eksternal (Robbins and Judge, 2012). Faktor internal yang dimaksud adalah proses mental yang terjadi dalam masing-masing individu, sedangkan faktor eksternal dapat berasal dari keadaan sosial yang ada di sekelilingnya dan waktu pada saat individu mengambil suatu tindakan atau perilaku.

Kehidupan mahasiswa yang lebih banyak menghabiskan waktu bersama teman-temannya, sangat memungkinkan bahwa persepsi mereka dalam proses pengambilan keputusan atas dirinya lebih banyak dipengaruhi oleh lingkungan sosialnya. Pendapat atau pengalaman teman seringkali menjadi pertimbangan yang paling banyak diacu dalam melakukan suatu perilaku kesehatan, termasuk dalam upaya pencarian pengobatan.

Seorang individu akan mengambil tindakan untuk melindungi diri sendiri ataupun mencari tindakan pengobatan jika mereka beranggapan bahwa masalah kesehatan yang sedang diderita adalah masalah yang serius. Jika responden menanggapi masalah kesehatan secara negatif, akan menimbulkan ancaman untuk dirinya sehingga dapat memicu individu untuk melakukan pencarian pengobatan. Mahasiswa sebagai responden seharusnya dapat mengukur keseriusan terhadap kondisinya saat mengalami gangguan kesehatan. 
Menurut Brehm (2014) Perceived susceptibility merupakan anggapan individu mengenai kemungkinan dirinya untuk tertular suatu penyakit atau penyakit tersebut bertambah parah. Tabel 4 menunjukkan gambaran persepsi kerentanan terhadap timbulnya perilaku pencarian pengobatan (Brehm, 2014).

Tabel 4 dapat diketahui bahwa sebanyak 16 orang merasa dirinya rentan untuk terserang penyakit yang lebih parah memilih untuk melakukan upaya pencarian pengobatan saat menderita gangguan kesehatan. Namun, proporsi mahasiswa yang merasa tidak rentan dan melakukan pencarian pengobatan jumlahnya lebih besar, yakni sebanyak 20 responden. Kondisi tersebut menunjukkan bahwa mahasiswa memiliki kesadaran dan pemahaman yang baik untuk melakukan pencegahan agar gejala penyakit yang diderita tidak menjadi lebih parah. Salah satu hal yang mungkin menjadi faktor baiknya pemahaman responden untuk melakukan upaya pencarian pengobatan adalah karena seringnya mereka terpapar informasi tentang kesehatan di bangku perkuliahan, sehingga berdampak pada pola pikir tentang konsep sehat dan sakit.

Tabel 4. Gambaran perceived susceptibility yang dirasakan terhadap health seeking behavior pada mahasiswa FKM UNAIR tahun 2018

\begin{tabular}{|c|c|c|c|c|c|c|c|}
\hline \multirow{3}{*}{$\begin{array}{c}\text { Perceived } \\
\text { Susceptibility }\end{array}$} & \multicolumn{4}{|c|}{ Pencarian Pengobatan } & \multirow{2}{*}{\multicolumn{2}{|c|}{ Total }} & \multirow{3}{*}{$\begin{array}{c}P \\
\text { Value }\end{array}$} \\
\hline & \multicolumn{2}{|c|}{ Tidak } & \multicolumn{2}{|c|}{$\mathrm{Ya}$} & & & \\
\hline & Frekuensi & $\%$ & Frekuensi & $\%$ & Frekuensi & $\%$ & \\
\hline Tidak Rentan & 15 & 42,9 & 20 & 57,1 & 35 & 100 & 0.005 \\
\hline Rentan & 45 & 73,8 & 16 & 26,2 & 61 & 100 & 0,005 \\
\hline
\end{tabular}

Masih banyak responden yang masih mengabaikan masalah kesehatan yang dialami walaupun dia merasa rentan dan khawatir dengan keadaannya. Kondisi dapat dilihat bahwa sebanyak 73,8\% mahasiswa merasa rentan dengan masalah kesehatan yang dialaminya namun tidak melakukan upaya pencarian pengobatan, dimana mereka lebih memilih istirahat hingga kondisinya kembali pulih.

Nilai $\mathrm{p}$ yang diperoleh dari hasil uji korelasi chi square menunjukkan angka sebesar 0,005 pada taraf signifikansi sebesar 5\%. Sehingga dapat diinterpretasikan bahwa terdapat signifikansi hubungan antara persespi kerentanan (perceived susceptibility) dengan perilaku pencarian pengobatan pada mahasiswa Fakultas Kesehatan Masyarakat Universitas Airlangga. Studi yang dilakukan Trisnawan (2015) juga didapatkan hasil bahwa persepsi kerentanan memiliki signifikansi hubungan dengan perilaku mahasiswa untuk melakukan pencarian pengobatan.

Persepsi kerentanan mengacu pada penilaian subjektif individu terhadap risiko dari masalah kesehatan yang diderita. Onoruoiza (2015) individu yang merasa memiliki risiko rendah terhadap suatu penyakit cenderung tidak melakukan hal yang mengarah pada upaya kesehatan (Onoruoiza et al., 2015). Sedangkan individu yang merasa dirinya memiliki risiko yang tinggi (rentan) terserang masalah kesehatan cenderung akan melakukan upaya kesehatan, baik pencegahan maupun melakukan pencarian pengobatan.

Kondisi tersebut sejalan dengan teori Health Belief Model, dimana saat seseorang memiliki persepsi rentan terhadap keadaan diri, maka peluang untuk melakukan upaya kesehatan akan lebih besar. Menurut penelitian yang dilakukan Ulvah (2011) di Universitas Jember yang berkaitan dengan perilaku pencarian pengobatan pada mahasiswa fakultas kesehatan dan non-kesehatan diperoleh hasil, bahwa faktor disiplin ilmu yang dipelajari memberikan pengaruh terhadap perilaku pencarian pengobatan (Ulvah, 2014).

Adanya paparan informasi atau pengetahuan tentang konsep sehat dan sakit lebih banyak diterima oleh mahasiswa kesehatan. Sehingga hal tersebut seharusnya dapat mempengaruhi mahasiswa kesehatan masyarakat untuk mencari pengobatan saat mengalami gangguan kesehatan.

Porche (2004) menyatakan Perceived benefit merujuk pada persepsi individu tentang efektifitas perilaku yang disarankan dalam rangka mengurangi risiko kesehatan (Porche, 2004). Tabel 5 dapat diketahui bahwa sebanyak 34 atau $38,6 \%$ responden yang memiliki persepsi manfaat langsung melakukan pencarian pengobatan untuk mengatasi masalah 
kesehatan ataupun mengurangi risiko kesehatan yang mungkin timbul.

Responden yang beranggapan bahwa melakukan tindakan pengobatan memiliki manfaat terhadap dirinya, namun mereka tidak melakukan pencarian pengobatan jumlahnya mencapai $61,4 \%$.
Jumlah tersebut, mengindikasikan bahwa gejala sakit yang dialami oleh responden beberapa waktu yang lalu tidak dianggap sebagai suatu hal yang serius, sehingga berdampak pada munculnya persepsi manfaat yang didapat ketika responden akan melakukan tindakan pengobatan.

Tabel 5. Gambaran perceived benefit yang dirasakan terhadap health seeking behavior pada mahasiswa FKM UNAIR tahun 2018

\begin{tabular}{|c|c|c|c|c|c|c|c|}
\hline \multirow{3}{*}{ Perceived Benefit } & \multicolumn{4}{|c|}{ Pencarian Pengobatan } & \multirow{2}{*}{\multicolumn{2}{|c|}{ Total }} & \multirow{3}{*}{ P Value } \\
\hline & \multicolumn{2}{|c|}{ Tidak } & \multicolumn{2}{|l|}{$\mathrm{Ya}$} & & & \\
\hline & Frekuensi & $\%$ & Frekuensi & $\%$ & Frekuensi & $\%$ & \\
\hline Tidak Bermanfaat & 6 & 75,0 & 2 & 25,0 & 8 & 100 & \\
\hline Bermanfaat & 54 & 61,4 & 34 & 38,6 & 88 & 100 & 0,706 \\
\hline
\end{tabular}

Uji hubungan dengan menggunakan chi square didapatkan $p$-value sebesar 0,706 dengan a sebesar $5 \%$, maka angka tersebut menunjukkan bahwa tidak ada signifikansi hubungan antara perceived benefit dengan perilaku pencarian pengobatan di kalangan mahasiswa Fakultas Kesehatan Masyarakat Universitas Airlangga.

Kondisi ini mengindikasikan jika mahasiswa yang memiliki persepsi melakukan tindakan pengobatan memiliki manfaat terhadap dirinya, tidak memiliki andil terhadap determinasi perilaku pencarian pengobatan. Walaupun banyak responden yang merasa bahwa tindakan pencarian pengobatan bermanfaat dalam proses kesembuhan, namun banyak dari mereka beranggapan bahwa dengan tidak melakukan tindakan pengobatan gejala sakit yang dialami dapat sembuh dengan sendirinya.

Mahasiswa kesehatan masyarakat yang menjadi responden dianggap memiliki pengetahuan dan pengalaman yang bisa digunakan untuk menilai kondisi diri mereka karena mendapat paparan informasi yang cukup banyak tentang kesehatan. Anggapan tersebut dapat mempengaruhi pola berpikir dalam mengambil keputusan.

Faktor predisposisi maupun faktor yang memungkinkan terwujudnya perilaku pencarian pengobatan ke dalam suatu tindakan nyata akan muncul jika individu merasa butuh untuk melakukannya (Notoatmodjo, 2010). Meskipun perilaku pencarian pengobatan dianggap berguna bagi individu, namun jika ia tidak menganggapnya sebagai kebutuhan, maka kecil kemungkinan untuk terwujud menjaditindakan pencarian pengobatan.
Riset yang dilakukan oleh Raflis (2013) kepada mahasiswa di Universitas Sumatera, diperoleh hasil bahwa teman memiliki pengaruh yang cukup kuat terhadap timbulnya perilaku pencarian pengobatan pada mahasiswa (Keloko, Harahap and Raflis, 2013). Nasehat atau pengalaman dari teman dapat berperan sebagai salah satu aspek yang memiliki dampak pada penerimaan persepsi manfaat seseorang, sehingga bepengaruh pada keputusan untuk mencari pengobatan.

Perceived barrier dapat didefinisikan sebagai hambatan yang dapat mencegah seseorang untuk mengambil tindakan atau mengadopsi suatu perilaku kesehatan. Tabel 6 menunjukkan potret persepsi hambatan atau kendala yang dirasakan terhadap perilaku pencarian pengobatan. Sebanyak 29 responden yang merasa tidak ada hambatan langsung melakukan upaya pencarian pengobatan guna mengatasi masalah kesehatan yang dialami. Selain itu, juga terdapat 29 responden yang merasa memiliki hambatan, dan berdampak pada pilihan untuk tidak melakukan upaya pencarian pengobatan saat mengalami gangguan kesehatan.

$\mathrm{Uji}$ hubungan dengan menggunakan chi square didapatkan $p$-value sebesar 0,009 pada taraf signifikansi $5 \%$. Hasil tersebut menunjukkan bahwa persepsi hambatan yang dimiliki oleh mahasiswa memiliki hubungan dengan perilaku pencarian pengobatan di kalangan mahasiswa Fakultas Kesehatan Masyarakat UNAIR.

Hasil kuesioner diperoleh hasil bahwa hambatan yang paling banyak dihadapi oleh mahasiswa adalah adanya rasa khawatir terhadap dampak atau efek 
negatif yang dapat ditimbulkan jika terlalu banyak atau sering mengonsumsi obat-obatan dengan persentase sebesar $84,1 \%$. Kondisi tersebut mengindikasikan mahasiswa telah memiliki infomasi yang baik bahwa obat memiliki efek negatif bagi tubuh jika dikonsumsi terlalu sering dan tidak sesuai dosis.

Selain hambatan tentang dampak negatif yang dapat ditimbulkan dari konsumsi obat terlalu sering, hambatan lainnya yang dihadapi oleh mahasiswa saat mengalami gangguan kesehatan adalah timbulnya rasa malas untuk pergi mencari pengobatan dengan persentase sebesar 36,7\%. Rasa malas memang menjadi salah satu faktor terbesar yang menghalangi mahasiswa untuk melakukan suatu hal, mahasiswa akan lebih memilih istirahat dan tidak mengindahkan gejala sakit yang dialami.

Tabel 6. Gambaran perceived barriers yang dirasakan terhadap health seeking behavior pada mahasiswa FKM UNAIR tahun 2018

\begin{tabular}{|c|c|c|c|c|c|c|c|}
\hline \multirow{3}{*}{$\begin{array}{c}\text { Perceived } \\
\text { Barriers }\end{array}$} & \multicolumn{4}{|c|}{ Pencarian Pengobatan } & \multirow{2}{*}{\multicolumn{2}{|c|}{ Total }} & \multirow{3}{*}{ P Value } \\
\hline & \multicolumn{2}{|c|}{ Tidak } & \multicolumn{2}{|l|}{$\mathrm{Ya}$} & & & \\
\hline & Frekuensi & $\%$ & Frekuensi & $\%$ & Frekuensi & $\%$ & \\
\hline Tidak Ada & 31 & 51,7 & 29 & 48,3 & 60 & 100 & $0 \cap 00$ \\
\hline Ada Hambatan & 29 & 80,6 & 7 & 19,4 & 36 & 100 & \\
\hline
\end{tabular}

Keseimbangan antara keuntungan yang diperoleh dan hambatan yang dihadapi memiliki kemungkinan untuk mempengaruhi seseorang dalam berperilaku, termasuk perilaku pencarian pengobatan. Akan tetapi, jumlah responden yang merasa tidak ada hambatan namun tidak melakukan pencarian pengobatan lebih besar memiliki jumlah yang cukup besar, yakni sebanyak 31 responden. Padahal semestinya, semakin rendah kendala yang ditemui atau dirasakan dapat mendorong seseorang untuk mengerjakan suatu perilaku tertentu.

Penelitian yang dilakukan Afolabi (2013) pada mahasiswa di Nigeria menyatakan bahwa perilaku pencarian pengobatan mahasiswa di negara tersebut dipengaruhi oleh sifat penyakit, lama waktu tunggu serta sikap tenaga kesehatan yang ada di pelayanan kesehatan (Afolabi et al., 2013). Kondisi tersebut mengindikasikan bahwa hambatan eksternal yang berasal dari pelayanan kesehatan juga memiliki pengaruh terhadap perilaku mahasiswa dalam mencari pengobatan.

Ketersediaan pusat layanan kesehatan (PLK) di Universitas Airlangga ternyata belum mampu mendorong para mahasiwa untuk melakukan tindakan pengobatan disana. Salah satu hal yang paling sering diutarakan mahasiswa setelah berobat disana adalah pelayanan yang kurang baik. Sehingga menyebabkan mahasiswa enggan pergi ke PLK saat mengalami gangguan kesehatan.
Kurangnya kualitas pelayanan yang ada di pusat layanan kesehatan universitas menjadi salah satu faktor yang dapat mempengaruhi perilaku pencarian pengobatan di kalangan mahasiswa.

\section{SIMPULAN}

Sebagian responden berjenis kelamin perempuan, mayoritas responden ada pada rentang usia >19-21 tahun, dengan tingkat kepemilikan asuransi yang cukup tinggi, namun masih rendah dalam hal pemanfaatan asuransi saat melakukan tindakan pengobatan. Perilaku pencarian pengobatan pada individu dapat dipengaruhi oleh sejumlah faktor, baik faktor dari dalam diri individu (internal) maupun luar individu (eksternal). Salah satu faktor internal yang bisa mempengaruhi munculnya perilaku pencarian pengobatan pada mahasiswa Fakultas Kesehatan Masyarakat UNAIR adalah persepsi individu.

Persepsi individu yang dijadikan sebagai variabel penelitian mengacu pada teori Health Belief Model dengan hasil yang menunjukkan bahwa persepsi keseriusan yang dirasakan oleh mahasiswa saat mengalami gangguan kesehatan mempunyai hubungan yang signifikan terhadap timbulnya perilaku pencarian pengobatan. Persepsi ada atau tidaknya hambatan dalam mewujudkan perilaku kesehatan juga mempunyai hubungan yang signifikan terhadap perilaku pencarian kesehatan pada mahasiswa Fakultas Kesehatan Masyarakat 
Universitas Airlangga. Persepsi kerentanan dan persepsi manfaat yang diperoleh tidak memiliki hubungan dengan timbulnya perilaku pencarian pengobatan.

\section{DAFTAR PUSTAKA}

Adhyka, N., Bakti, A. and Lumongga, N. (2013) 'Gambaran Perilaku Mahasiswa Serumpun Fakultas Kesehatan Universitas Sumatera Utara Terhadap Proses Pencarian Pengobatan Di Kota Medan Tahun 2013', Jurnal Kebijakan, Promosi Kesehatan dan Biostatistik, 2(3), pp. 1-6.

Afolabi, M. O. et al. (2013) 'Healthseeking Behaviour and Student Perception of Health Care Services in a University Community in Nigeria', Health, 5(5), pp. 817-824.

Al-ameri, R. J. K., Al-badri, H. J. A. and Lafta, R. K. (2016) 'Prevalence of self-medication among university students in Baghdad: a cross-sectional study from Iraq', Eastern Mediterranean Health Journal, 23(2), pp. 87-93.

Badan Pusat Statistik (2009) Survei Sosial Ekonomi Nasional 2009 Semester 1 (Panel). Jakarta.

Badan Pusat Statistik (2015) Survei Sosial Ekonomi Nasional 2015 Maret (Modul). Jakarta.

Badan Pusat Statistik (2017) Survei Sosial Ekonomi Nasional 2017 Maret (KOR). Jakarta.

Bennadi, D. (2013) 'Self-medication: A current challenge', Journal of basic and clinical pharmacy. Medknow Publications \& Media Pvt Ltd, 5(1), pp. 19-23. doi: 10.4103/0976-0105.128253.

Brehm, B. (2014) Psychology of Health and Fitness: Applications for Behavior Change. United States: F.A. Davis Company.

Dawood, O. T. (2017) 'Factors affecting knowledge and practice of medicine use among the general public in the State of Penang, Malaysia', Journal of Pharmaceutical Health Services Research, 8(1), pp. 51-57.

Iswandi, E. (2017) Gambaran Pola Pencarian Pengobatan Pada Masyarakat Suku Alas Di
Kecamatan Bukit Tusam Kabupaten Aceh Tenggara Tahun 2017.

Keloko, A. B., Harahap, S. and Raflis, R. (2013) 'Pengaruh Agen Sosialisasi terhadap Pola Pencarian Pengobatan Mahasiswa Rumpun Fakultas Non-eksakta Universitas Sumatera Utara di Kota Medan Tahun 2013', Kebijakan, Promosi Kesehatan dan Biostatistika, 2(3).

Kementerian Kesehatan RI (2010) Riset Kesehatan Dasar. Jakarta.

Noor, M. (2015) Memotret Data Kuantitatif. Semarang: Duta Nusindo Semarang.

Notoatmodjo, S. (2010) Ilmu Perilaku Kesehatan. Semarang: Duta Nusindo Semarang.

Onoruoiza, S. I. et al. (2015) 'Using Health Beliefs Model as an Intervention to Non Compliance with Hypertension Information among Hypertensive Patient', IOSR Journal of Humanities And Social Science, 20(9), pp. 11-16.

Porche, D. J. (2004) Public \& Community Health Nursing Practic. USA: Sage Publications.

Robbins, S. P. and Judge, T. A. (2012) Essentials of Organizational Behavior, 11th Edition. San Diego: Pearson.

Rosenstock, I., Strecher, V. and Becker, M. (1988) 'Social learning theory and the Health Belief Model', Health Education Quarterly, 15(2), pp. 175-183.

Rumengan, D. S. S., Umboh, J. M. L. and Kandou, G. D. (2015) 'Faktorfaktor yang Berhubungan dengan Pemanfaatan Pelayanan Kesehatan pada Peserta BPJS Kesehatan di Puskesmas Paniki Bawah Kecamatan Mapanget Kota Manado', JIKMU, 5(1).

Supriyanto, S. and Ernawati (2010) Pemasaran Industri Jasa Kesehatan. Yogyakarta: CV Andi Offset.

Trisnawan, P. D. (2015) Determinan Perilaku Pencarian Pengobatan Mahasiswa Fakultas Kedokteran dan IImu Kesehatan UIN Syarif Hidyatulah Jakarta Angkatan Tahun 2013. UIN Syarif Hidayatullah Jakarta.

Ulvah, M. L. (2014) Faktor yang 
Berpengaruh terhadap Perilaku Pencarian Pengobatan pada Mahasiswa di Lingkungan Fakultas Kesehatan dan Non Kesehatan Universitas Jember. Universitas Negeri Jember.
Vaz, F., Ferreira, A. and Kulkarni, M. S. (2012) 'Study of health seeking behavior among medical students in Goa, India', Asian Journal of Medical and Clinical Sciences, 1, pp. 140-141. 